\title{
Game Design as A Character Education Media For Children
}

\author{
Michael Marchiano \\ Department of Information System, Faculty of Computer Science, \\ Soegijapranata Catholic University, Semarang, Indonesia \\ nyo150996@gmail.com
}

\begin{abstract}
In the present era many children are contaminated with negative things from the internet due to lack of supervision from parents so that there are many verbal and nonverbal abuse. The many of children who do not behave according to age so that requires a character education media that can provide understanding of the character in the self, especially the self-confidence for children so as to be yourself and not fall into the negative.
\end{abstract}

Keyword - character education, confident, child

\section{INTRODUCTION}

Increasing crime and violence in a nation is due to the declining moral quality of a nation. The low level of dishonesty, irresponsibility, and lack of a sense of commitment to virtue values contains a nation and a state leading to the brink of destruction. Which is where there is a need for a proper step to make the present generation by instilling moral values that can make them the successor of the nation to be more advanced for the welfare and prosperity of the common people.

Therefore character education needs a media that can provide effectiveness and efficiency that supports the development of various models of character education that is innovative and creative so that in the delivery of material is not boring.

It also as a tool in facilitating the delivery of material that is classified as complex and complex.

Based on research conducted by Otago University in Dunedi, New Zealand against 1000 children aged 3 years studied for 23 years since 1972. It is evident that the diagnosed child is difficult to organize, dissidents and grumpy will be an unruly and aggressive teenager.

As adults they are difficult to foster a good relationship with the surrounding community. Unlike a child who has a healthy soul, as an adult will become a successful person. From the research that has been done, many experts argue that at the age of teenagers is 12 to 20 years, is considered to be too late to receive character education [1]. This is because in the personality of a teenager will appear the crisis between the identity itself due to the occurrence of puberty, causing the possibility of conflict of confidence, sexuality, work, and others.

So the child needs to have self-confidence that is destined as initial capital to achieve ego perfection at the end of this teenage phase [2].

Character education is not just simply given but also the need for cooperation between parents and educators to make children feel that they are accepted, needed, loved, valued, and supported by others. So from the attention given to a child's can make person who is pro-social, confident, and independent but still concerned with the environment. A child with self-confidence will become a person who is able to understand his inner abilities objectively and rationally and realistically. So if expectations can not be realized, the child is not easily discouraged that led to depression [1].

According to Lauster, an individual with positive self-esteem will have an attitude to take care of and nourish himself, understand himself and not only contemplate himself but also act, and think about the feelings of others. Actions that will be done usually have a clear purpose and do not invite conformist nature and can be accepted by the community. The views are always positive on all things and 
difficulties, so he can control everything well and not rely on others.

It can be concluded that children with good character education will have a good sense of confidence including aspects of self, optimistic spirit, responsibility, objective thinking, and thinking based on rationality and reality [3].

The purpose of this paper is to design the game as a good character education media for children who are packaged for easy understanding by children.

\section{METHOD}

\section{A. Character Building}

According to Law no. 20 year 2003 Article 1 paragraph 1, education is a conscious and planned effort to create an atmosphere of learning and learning process so that learners actively develop their potential to have spiritual spiritual strength, self-control, personality, intelligence, noble character, and skills needed him, society, nation, and country [4].

Based on the Law on National Education, education not only focuses on improving the understanding and guidance of science and skills, but also needs to be inserted about the development of personality and character of each individual student with maturity, so have thought rasional, empathy, can control emotions, and able to develop peace in social life. [5]

The character education is a conscious effort made to develop a good character based on virtue values so as to be useful to oneself and society. [6]

\section{B. Character}

The character itself comes from the Greek word karasso which means 'blueprint', 'basic format', or 'fingerprint'. Another opinion states the character comes from the Greek word charassein which means 'make sharp' or 'make in'. According to the Great Dictionary of Indonesian Language, character is the nature - the nature of psychology, ahklak or manners that distinguish someone from the other; nature; character.

Conceptually character is divided into 2 terms, namely 1) a character that is deterministic which is understood as a collection of spiritual conditions that are awarded from birth. 2) the character is non deterministic understood as the level of individual toughness in an effort to perfect the spiritual condition that has been given.

\section{Self-Confidence}

According to Breneche and Amich, selfconfidence is a sense of understanding what is needed by his life so that the individual is not necessary to compare life in himself with others.

Lauster argues that people with self-esteem can appreciate others because the individual assumes that everyone has the same ability as himself.

But conversely with less confident individuals will have difficulty in dealing with others, less responsible, pessimistic and likes to compare themselves with others [3].

\section{Aspects of Self-Confidence}

Individuals who have excessive selfesteem will make the individual do as he pleased himself and can make himself in conflict with others. The type of person who has positive self-esteem will be able to associate with people, have tolerance, look calm, and not easily influenced by others in solving a problem. Here are the aspects aspects possessed by individuals with positive confidence:

1. Confidence in Yourself

Belief in yourself for what it will do seriously

2. To be responsible

Individual readiness to bear all the things that have become consequences that will or have done.

3. Objective Thought

Thoughts are not based on their own assumptions but are based on the existingness.

4. Rationality and Reality

The analysis of a problem or event is based on reality and is acceptable to the civilized human mind.

5. Optimism

The positive attitude an individual possesses when facing a problem or difficulty in an always good view.[7] 


\section{E. Game Development}

In the process of game development, data collection is done to form the concept of the game to be created but still there are elements of educating for children. The data were collected based on literature studies on character education books, interviews with expert sources, and questionnaires distributed to the respondents. After that began to make asset form of characters, background, animation, and other support for the game becomes more interesting. Followed by the stage of making the program while testing to try if there are still errors or errors in the program before ready to play. Here's a flowchart in the game development process:
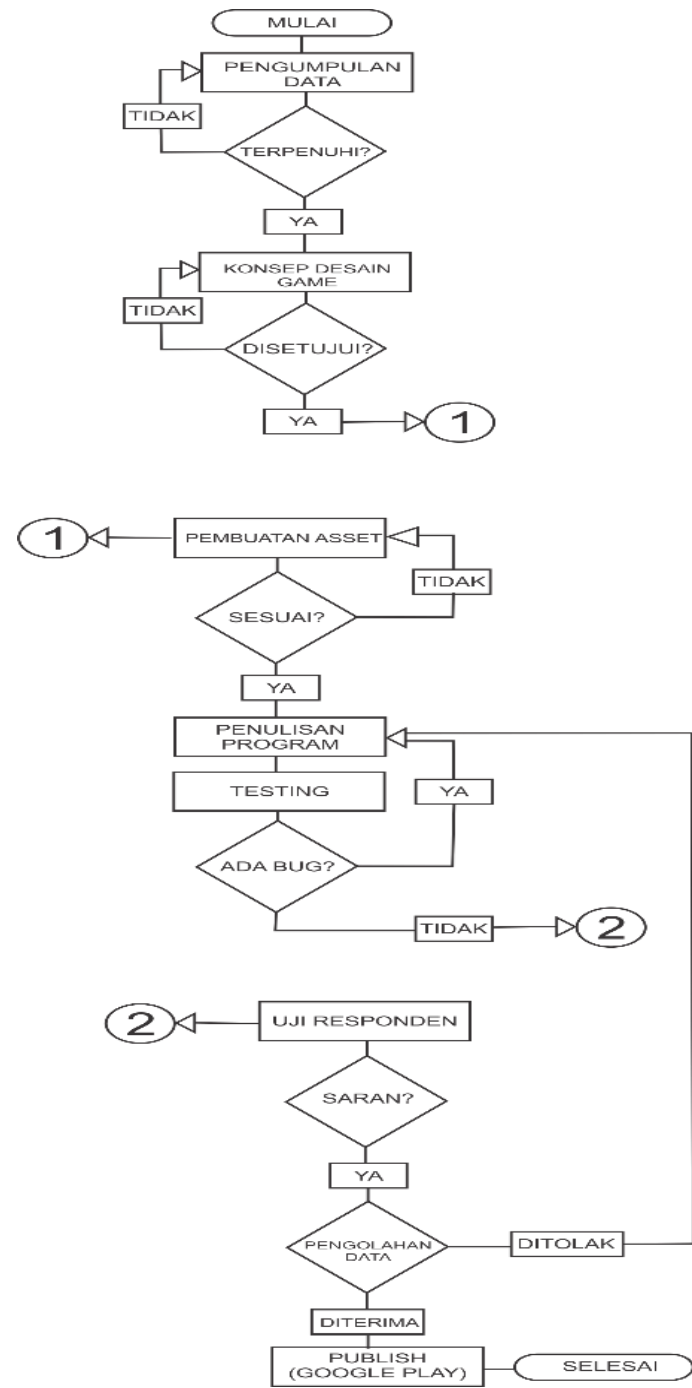

Figure 1. Game Development Flowchart
III. RESULT AND DISCUSSION

\section{A. Game Design}

The process of game design begins with the design of plots and concepts rather than the game. Here's a good character education game design for children:

1. Score and Reward

If the first player first plays this game, the player is required to play it from start to stage 1 to stage 5 . On stage 1 , if the player answers correctly will get a score of 4 points, stage 2 of 5 points, stage 3 of 7 points, stage 4 by 10 points, and stage 5 by 17 points. Scores made will always increase from stage 1 to stage 5 . If the player answers with the wrong answer, it will not get a score. At the end of the game, players will be given a display of the results of each stage that has been played and accumulated. And if the result is more than $50 \%$ then will be rewarded in the form of mini game to give spirit to the players.

2. Question

The questions asked in the game are taken from the book based on the Pendidikan 9 Pilar Karakter which is then reprocessed according to the understanding of children ages 7 to 10 years and then consulted with expert interviews who is one of the lecturers of psychology at the Catholic University of Soegijapranata so that the values that want submitted can be well understood. In addition, some answer buttons are also made not only in a text, but also in the images.

Because the child more easily understand more deeply when explained through pictures and colors.

\section{Theme}

Educational media that provide a good understanding of the character for children need to pay attention to the principles and aspects of character education so that it can educate children to be better, namely moral knowledge, knowledge of feelings, and moral behavior. Therefore taking the theme of character education for children aged 7 to 10 years can be one alternative media that provides understanding and understanding of the curiosity of children who can be directed to be positive and full of confidence that includes the five aspects of self-belief, 
responsibility, objective thinking, optimism, and rationality \& realistic.

\section{B. Gameplay}

Gameplay is based on data sources that have been collected in order to provide understanding and understanding of good character especially confidence. In addition to fun, games can also be used to provide educational values to players in the form of questions that are organized into a quiz. The question posed is a question based on the daily life difficulties commonly encountered by children aged 7 to 10 years.

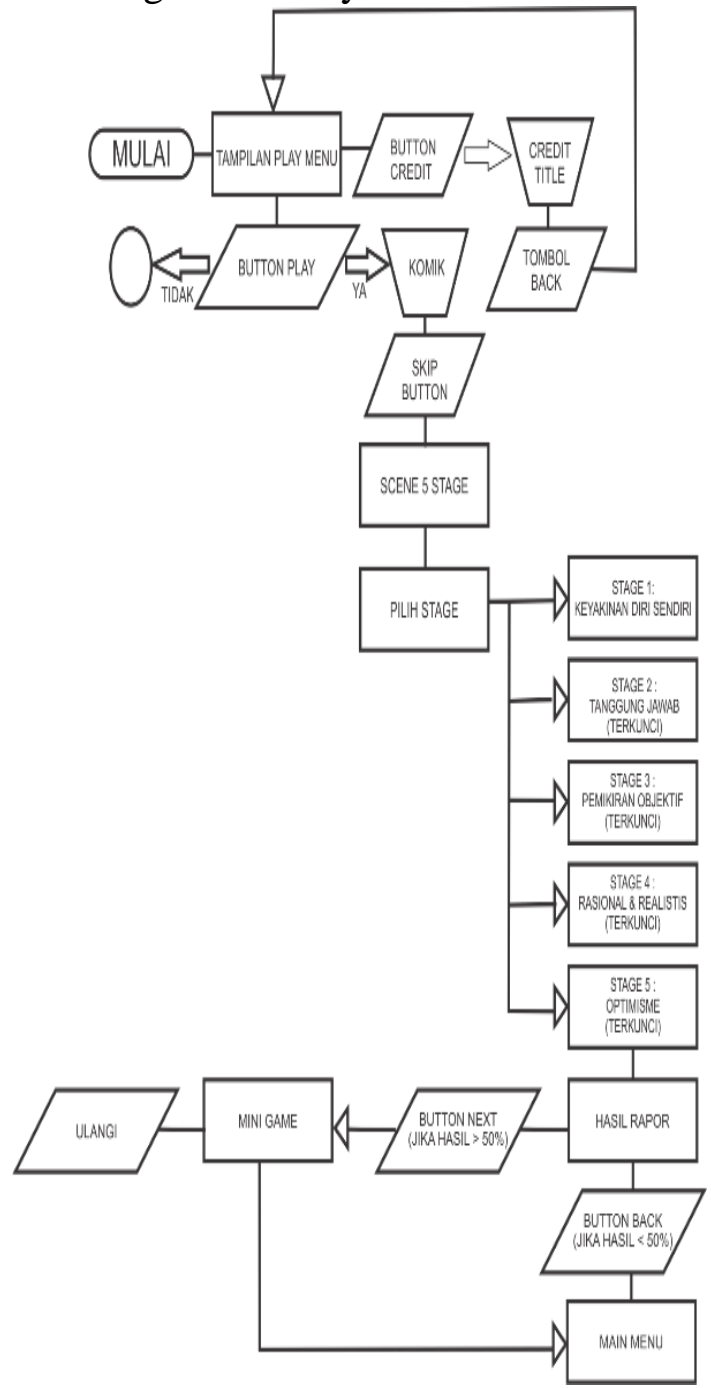

Figure 2. Game Flow in Flowchart
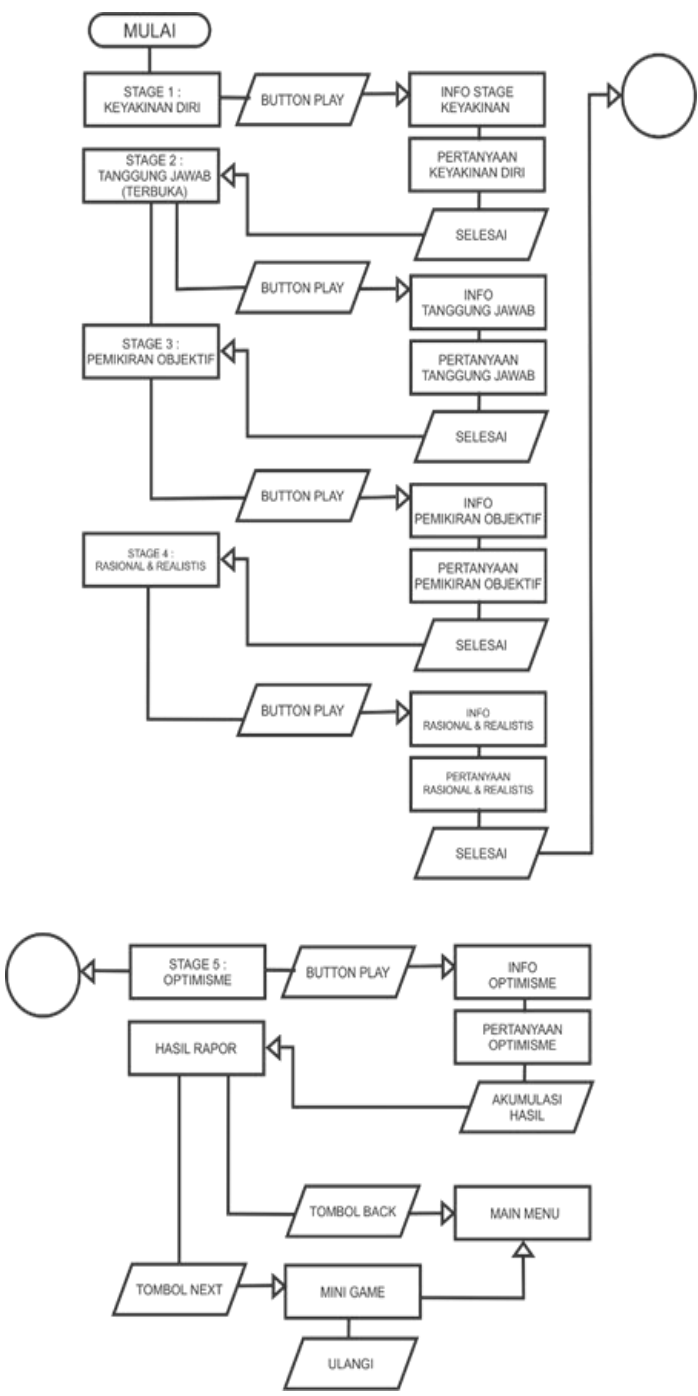

Figure 3. Game Stage Flowchart

\section{Game View}

Display images are made in colorful and by using bright colors to make children more enthusiast and happy. In addition, the values entered into the game can be delivered properly so it will be easy to remember by the child rather than just a black and white writing only. Here's how the game looks:

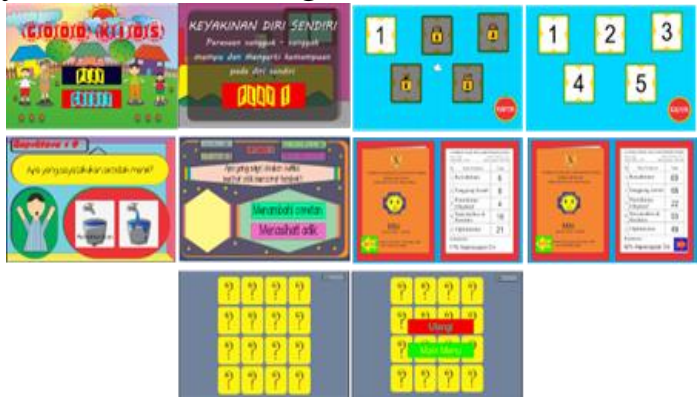

Figure 4. Game Display

\section{Impact Game}

Through questionnaires that have been disseminated before making games and after 
the children play the game, there is a significant change in knowledge of the aspects of self-confidence that include: self-belief, responsibility, optimism, objective thinking, and rationality \& realistic. Here's a graph of the impact impact of confidence before playing and after playing the game:

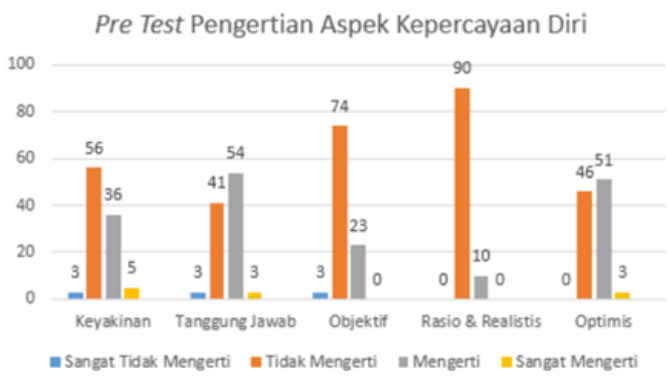

Figure 5. Pre Test Confidence Aspect

Post Test Pengetahuan Aspek Kepercayaan Diri

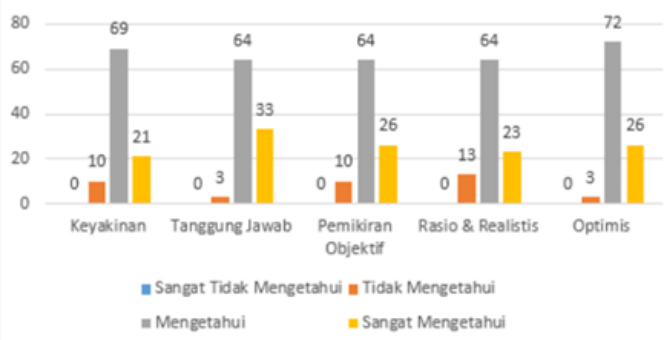

Figure 6. Post Test Confidence Aspect

\section{CONCLUSION}

In designing games as a good character education media for children need to incorporate the principles of good character education that can be delivered through gameplay. So the values to be conveyed can be easily understood by the child. This is indicated by a significant change in the graph on the impact of the game. Colorful display also makes it easy for children to remember the values of character education delivered through the game.

\section{REFERENCES}

[1] W. Kramer, "What is a Game?," www.thegamesjournal.com, 2000. [Online]. Available: http://www.thegamesjournal.com/articl es/WhatIsaGame.shtml. [Accessed: 30Aug-2016].

[2] H. Bastian and Khamadi, "Dampak Digital Game Terhadap Perkembangan Sosial Budaya Masyarakat,"
Andharupa, vol. 2, no. 1, pp. 33-44, 2016.

[3] K. Khoshelham and S. O. Elberink, "Accuracy and resolution of kinect depth data for indoor mapping applications," Sensors, vol. 12, no. 2, pp. 1437-1454, 2012.

[4] C. White, "Kinect 101: Introduction to Kinect for Windows," p. 1, 2014.

[5] -, "Thirty-Four Percent Of Top Games Are Made With Unity," unity3d.com. [Online].

Available: https://unity3d.com/public-relations. [Accessed: 30-Aug-2016].

[6] A. Luthfi, "Mengenal Unity, Engine Game Untuk Developer," celebrity.okezone.com, 2014. [Online]. Available:

http://celebrity.okezone.com/read/2014 /11/28/207/1071900/mengenal-unityengine-game-untuk-developer.

[Accessed: 30-Aug-2016]. 